CORRECTION

\title{
Correction: Influenza A Virus NS1 Protein Inhibits the NLRP3 Inflammasome
}

\author{
Woo-Chang Chung, Hye-Ri Kang, Hyunyee Yoon, Suk-Jo Kang, Jenny P.-Y. Ting, Moon \\ Jung Song
}

The first author's name is spelled incorrectly. The correct name is: Woo-Chang Chung. The correct citation is: Chung W-C, Kang H-R, Yoon H, Kang S-J, Ting JP-Y, Song MJ (2015) Influenza A Virus NS1 Protein Inhibits the NLRP3 Inflammasome. PLoS ONE 10(5): e0126456. https://doi.org/10.1371/journal.pone.0126456

\section{Reference}

1. Cheong W-C, Kang H-R, Yoon H, Kang S-J, Ting JP-Y, Song MJ (2015) Influenza A Virus NS1 Protein Inhibits the NLRP3 Inflammasome. PLoS ONE 10(5): e0126456. https://doi.org/10.1371/journal.pone. 0126456 PMID: 25978411

\section{G openaccess}

Citation: Chung W-C, Kang H-R, Yoon H, Kang SJ, Ting JP-Y, Song MJ (2018) Correction: Influenza A Virus NS1 Protein Inhibits the NLRP3 Inflammasome. PLoS ONE 13(7): e0200624. https://doi.org/10.1371/journal.pone.0200624

Published: July 10, 2018

Copyright: ๑ 2018 Chung et al. This is an open access article distributed under the terms of the Creative Commons Attribution License, which permits unrestricted use, distribution, and reproduction in any medium, provided the original author and source are credited. 